\title{
PENGARUH PENGEMBANGAN KARIR DAN LINGKUNGAN KERJA FISIK TERHADAP KEPUASAN KERJA DAN KINERJA KARYAWAN (STUDI PADA KANTOR CABANG PERUM DAMRI MATARAM)
}

\author{
Raden Bagus Faizal Irany Sidharta ${ }^{1}$ \\ ${ }^{1}$ Fakultas Ekonomi dan Bisnis Universitas Mataram, ronyfaizal93@gmail.com
}

\begin{abstract}
ABSTRAK
Penelitian ini bertujuan untuk mengetahui signifikansi pengaruh pengembangan karir terhadap kepuasan kerja, pengaruh lingkungan kerja fisik terhadap kepuasan kerja, pengaruh pengembangan karir terhadap kinerja, pengaruh lingkungan kerja fisik terhadap kinerja dan pengaruh kepuasan kerja terhadap kinerja. Jenis penelitian yang digunakan penelitian asosiatif, metode pengumpulan data yang digunakan dengan metode sensus, populasi berjumlah 91 karyawan. Teknik pengumpulan data menggunakan angket dan wawancara. Data yang telah dikumpulkan kemudian di analisa dengan menggunakan analisa jalur dengan memanfaatkan program aplikasi SPSS 16.0 For Windows. Hasil penelitian ini menujukkan bahwa, pengembangan karir $\left(\mathrm{X}_{1}\right)$ berpengaruh secara signifikan terhadap kepuasan kerja $\left(\mathrm{Y}_{1}\right)$ karyawan pada Kantor Cabang Perum DAMRI Mataram, lingkungan kerja fisik $\left(\mathrm{X}_{2}\right)$ berpengaruh secara signifikan terhadap kepuasan kerja $\left(\mathrm{Y}_{1}\right)$ karyawan pada Kantor Cabang Perum DAMRI Mataram, pengembangan karir $\left(\mathrm{X}_{1}\right)$ berpengaruh secara signifikan terhadap kinerja $\left(\mathrm{Y}_{2}\right)$ karyawan pada Kantor Cabang Perum DAMRI Mataram, lingkungan kerja fisik $\left(\mathrm{X}_{2}\right)$ berpengaruh secara signifikan terhadap kinerja $\left(\mathrm{Y}_{2}\right)$ karyawan pada Kantor Cabang Perum DAMRI Mataram, kepuasan kerja $\left(\mathrm{Y}_{1}\right)$ berpengaruh secara signifikan terhadap kinerja $\left(\mathrm{Y}_{2}\right)$ karyawan secara signifikan pada Kantor Cabang Perum DAMRI Mataram.
\end{abstract}

Kata Kunci: Pengembangan Karir, Lingkungan Kerja Fisik, Kepuasan Kerja, Kinerja.

\section{ABSTRACT}

The research aim is to find out the significant influence of carrier developing toward work satisfaction, the influence of physical work environment toward work satisfaction, the influence of carrier developing toward performance the influence of physical work environment toward performance and the influence of satisfaction toward performance, this id associative research data collecting method use census method, number of population are 91 employees, data collecting technique use questionnaire and interview, data collected later analyzed by path analysis and utilize the SPSS 16.0 windows program, research result shows carrier developing (X1) have significant influence toward work satisfaction (YI) the employee of branch office of Mataram Perum Damri physical work environment (X2) have significant influence toward work satisfaction (Y1) the employee of branch office of Mataram Perum Damri, carrier developing (X1) have significant influence toward performance (Y2) the employee of branch office of Mataram Perum Damri, physical work environment (X2) have significant influence toward performance (Y2) the employee of branch office of Mataram Perum Damri, work satisfaction (Y1) have significant influence toward performance (Y2) employee significantly influence toward branch office of Mataram Perum Damri.

Keyword: carrier developing, physical work environment, work environment, performance. 


\section{PENDAHULUAN}

Sumber daya manusia (SDM) merupakan hal yang terpenting dimiliki oleh sebuah perusahaan. Manusia merupakan penggerak dari setiap aktivitas yang ada dalam perusahaan sehingga penting bagi perusahan untuk memanage (mengelola) sumber daya manusia tersebut agar perusahaan dapat bertahan dan dapat mencapai tujuannya. Agar perusahaan dapat bertahan dalam waktu yang panjang dan dapat mencapai tujuannya, perusahaan perlu untuk memiliki karyawan yang berkinerja tinggi. Usaha untuk mempertahankan dan meningkatkan kinerja dari karyawan tersebut salah satunya dengan memperhatikan kepuasan kerja dari karyawan tersebut. Kepuasan kerja merupakan keadaan emosional yang menyenangkan atau tidak menyenangkan bagi para karyawan dalam memandang pekerjaan mereka. Menurut Gibson (2000:110) dalam Wibowo (2010), mengatakan bahwa secara jelas terdapat hubungan antara kepuasan kerja karyawan terhadap kinerja karyawan. Dikatakan kepuasan kerja menyebabkan peningkatan kinerja sehingga pekerja yang merasa puas akan lebih produktif dalam bekerja. Selain itu salah satu faktor yang mempengaruhi kepuasan kerja adalah dengan diberikannya karyawan kesempatan untuk maju. Menurut As'ad (2003) dalam Wahyuni (2012) kesempatan untuk maju adalah adanya kesempatan bagi setiap karyawan untuk memperoleh pengalaman dan peningkatan kemampuan selama kerja. Pengembangan karir merupakan salah satu cara yang dapat dilakukan untuk memberikan kesempatan maju bagi karyawan. Pengembangan karir adalah suatu kemungkinan-kemungkinan seorang karyawan sebagai individu dapat naik pangkat atau jabatan yang dihubungkan dengan kemampuan dan persyaratan karyawan tersebut sehingga dapat tercapai kepuasan kerja yang mendorong peningkatan kinerja dan perkembangan pribadinya, disesuaikan dengan dengan rencana yang telah diatur oleh perusahaan (Soeprihantono, 2000). Selain itu untuk meningkatkan kepuasan dan kinerja karyawan faktor yang perlu diperhatikan oleh perusahaan adalah lingkungan kerja fisik. Menurut Sedarmayanti (2009), lingkungan kerja fisik adalah semua keadaan berbentuk fisik yang terdapat di sekitar tempat kerja di mana dapat mempengaruhi karyawan baik secara langsung maupun tidak langsung. Menurut Nitisemito (1984:183), lingkungan kerja fisik merupakan kondisi yang terdapat disekitar tempat kerja, di mana para karyawan beraktivitas dan menghasilkan produktivitas sehari-harinya. Tentunya hal tersebut menunjukkan bahwa lingkungan kerja fisik sangat berhubungan erat dengan pencapaian hasil kerja dari seorang karyawan. Menurut Nitisemito (1984:183), lingkungan kerja merupakan salah satu faktor yang menyebabkan semangat dan kegairahan kerja dalam pelaksanaan tugas. Ketika karyawan bersemangat dalam bekerja yang dicerminkan dengan baiknya kondisi lingkungan kerja fisiknya, maka pada saat itu terciptanya kepuasan kerja akan lingkungan kerja fisik dari karyawan tersebut. Lokasi penelitian ini berada pada Kantor Cabang Perum DAMRI Mataram dengan melayani rute perjalanan Mataram-Senggigi-Bandara (Bandara Internasional Lombok) dan Mataram-Pulau Sumbawa setiap harinya. Fenomena yang terjadi adalah adanya penurunan pencapaian kinerja pelayanan para karyawan dan berpengaruh pada kinerja perusahaan yang tercermin dari turunnya jumlah penumpang yang menggunakan transportasi Perum DAMRI tiap tahunnya 
Tabel 1. Jumlah Penumpang Perum DAMRI Mataram

\begin{tabular}{|c|c|c|}
\hline \multirow{2}{*}{ Tahun } & \multicolumn{2}{|c|}{ Rute } \\
\cline { 2 - 3 } & Mataram-Senggigi-Bandara & Mataram- Pulau Sumbawa \\
\hline $\mathbf{2 0 0 9}$ & 48765 & 95875 \\
\hline $\mathbf{2 0 1 0}$ & 46323 & 94321 \\
\hline $\mathbf{2 0 1 1}$ & 43688 & 111853 \\
\hline $\mathbf{2 0 1 2}$ & 42734 & 92067 \\
\hline $\mathbf{2 0 1 3}$ & 38927 & 90843 \\
\hline Total & $\mathbf{2 2 0 4 3 7}$ & $\mathbf{4 8 4 9 5 9}$ \\
\hline
\end{tabular}

Sumber data: Kantor Cabang Perum DAMRI Mataram

Dari tabel di atas dapat diketahui jumlah penumpang tiap tahunnya mengalami penurunan dalam 5 (lima) tahun terakhir. Untuk rute Mataram-SenggigiBandara pada tahun 2009 jumlah penumpang sebanyak 48.765 orang mengalami penurunan pada tahun 2010 menjadi 46.323 orang, begitupun pada tahun 2011 jumlah penumpang tersebut mengalami penurunan menjadi 43.688 orang. Pada tahun 2012 penurunan jumlah penumpang kembali terjadi dari tahun sebelumnya menjadi 42.734 orang diikuti dengan tahun 2013 kembali menurun dengan jumlah penumpang sebanyak 38.927 orang. Sedangkan untuk rute Mataram-Pulau Sumbawa menujukkan angka jumlah penumpang yang cenderung menurun. Pada tahun 2009 jumlah penumpang yang menggunakan DAMRI ke pulau Sumbawa sebanyak 95.875 orang lalu pada tahun 2010 mengalami penurunan menjadi 94.321 orang. Namun, pada tahun 2011 terjadi peningkatan terhadap jumlah penumpang tersebut menjadi 111.853 orang tetapi hal ini tidak bertahan lama karena pada tahun 2012 penurunan tersebut kembali terjadi menjadi 92.067 orang dan kembali mengalami penurunan pada tahun berikutnya yakni tahun 2013 menjadi 90.834 orang. Selain itu juga, pengembangan karir dalam hal ini pendidikan dan pelatihan (diklat) yang dilakukan oleh perusahaan tidak menentu pada bagian atau divisi yang dijadwalkan dipersiapkan oleh perusahaan sehingga mengakibatkan karyawan tidak bisa cepat untuk menuju jenjang karir yang telah direncanakan oleh karyawan itu sendiri dan membuat karyawan mengalami kebingungan dalam menentukan sasaran karir mereka yang mengakibatkan terjadinya penurunan kepuasan kerja dan berdampak pada penurunan kinerja karyawan itu sendiri serta lingkungan kerja fisik yang masih dirasakan tidak nyaman oleh karyawan. Terutama pada karyawan yang bekerja di luar ruangan kondisi fisik ini sangat-sangat mempengaruhi kondisi dari pekerjaannya ditambah lagi dengan minimnya fasilitas dalam bekerja. Penelitian yang dilakukan oleh Dewi dan Utama (2016) menemukan bahwa pengembangan karir berpengaruh positif dan signifikan terhadap kinerja karyawan, penelitian yang dilakukan oleh Dewa dan Rai (2013) menemukan bahwa pengembangan karir tidak berpengaruh terhadap kinerja karyawan, penelitian yang dilakukan oleh Lantara dan Utama (2014) lingkungan kerja fisik berpengaruh positif terhadap kinerja karyawan, penelitian yang dilakukan oleh Yulinda dan Harliyanti (2009) menemukan bahwa lingkungan kerja fisik tidak berpengaruh terhadap kinerja karyawan. Penelitian yang dilakukan oleh Gatot dan Adisasmito (2015) menemukan bahwa pengembangan karir berpengaruh terhadap kepuasan kerja, penelitian yang dilakukan mahlia (2010) menemukan bahwa pengembangan karir tidak berpengaruh terhadap kepuasan kerja, penelitian yang dilakukan oleh Pahmi et al (2015) menemukan bahwa kepuasan kerja berpengaruh 
positif dan signfikan terhadap kinerja dan penelitian yang dilakukan oleh Rai (2014) menemukan bahwa kepuasan kerja tidak berpengaruh terhadap kinerja karyawan.

\section{PERUMUSAHAN MASALAH}

Berdasarkan uraian pada latar belakang di atas, maka dapat dibuat perumusan masalah sebagai berikut:

a. Apakah pengembangan karir mempunyai pengaruh signifikan terhadap kepuasan kerja karyawan Kantor Cabang Perum DAMRI Mataram?

b. Apakah lingkungan kerja fisik mempunyai pengaruh signifikan terhadap kepuasan kerja karyawan Kantor Cabang Perum DAMRI Mataram?

c. Apakah pengembangan karir mempunyai pengaruh signifikan terhadap kinerja karyawan Kantor Cabang Perum DAMRI Mataram

d. Apakah lingkungan kerja fisik mempunyai pengaruh signifikan terhadap kinerja karyawan Kantor Cabang Perum DAMRI Mataram?

e. Apakah kepuasan kerja karyawan mempunyai pengaruh signifikan terhadap kinerja karyawan Kantor Cabang Perum DAMRI Mataram?

\section{KERANGKA TEORITIS DAN HIPOTESIS}

\section{Kerangka Teoritis}

\section{Pengertian Kinerja}

Menurut Wirawan (2009:5) kinerja adalah keluaran yang dihasilkan oleh fungsi-fungsi atau indikator-indikator suatu pekerjaan atau suatu profesi dalam waktu tertentu. Menurut Prawirosentono (1999:2), kinerja adalah hasil kerja yang dapat dicapai oleh seseorang atau sekelompok orang dalam suatu organisasi, sesuai dengan wewenang dan tanggung jawab masing-masing, dalam rangka upaya mencapai tujuan organisasi bersangkutan secara legal, tidak melanggar hukum dan sesuai dengan moral maupun etika. Menurut Wibowo (2012:7), kinerja adalah tentang melakukan pekerjaan dan hasil yang dicapai dari pekerjaan tersebut. Kinerja adalah tentang apa yang dikerjakan dan bagaimana cara mengerjakannya. Dengan demikian, dari beberapa pengertian di atas dapat disimpulkan kinerja adalah suatu hasil kerja yang nyata dan dapat dicapai oleh seseorang dalam melaksanakan tugastugas yang diberikan kepadanya. Seseorang dikatakan memiliki kinerja yang baik ketika mereka dapat memberikan hasil kerja yang telah ditetapkan sebelumnya dan bahkan melebihi standar pekerjaan yang telah ditentukan serta dapat memberikan kontribusi yang nyata pada perusahaan.

2. Indikator Pengukuran Kinerja

Menurut Tsui, Anne, Pearce dan Porter (1997) indikator pengukuran kinerja terdiri dari:
a) Kuantitas kerja karyawan
b) Kualitas kerja karyawan
c) Efisiensi karyawan
d) Standar kualitas karyawan
e) Kerja keras karyawan
f) Profesionalisme karyawan
g) Kemampuan karyawan
h) Kemampuan karyawan menggunakan akal sehat

56 | Pengaruh Pengembangan Karir Dan Lingkungan Kerja Fisik...... 

i) Ketepatan karyawan
j) Pengetahuan karyawan

\section{Pengertian Kepuasan Kerja}

Menurut Handoko (2012:193), kepuasan kerja adalah keadaan emosional yang menyenangkan atau tidak menyenangkan bagi para karyawan dalam memandang pekerjaan mereka. Kepuasan kerja mencerminkan perasaan seseorang terhadap pekerjaannya. Hal ini nampak dalam sikap positif karyawan terhadap pekerjaan dan segala sesuatu yang dihadapi di lingkungan kerjanya. Sedangkan menurut Davis dan John (1995:122) dalam Zulhana (2012), kepuasan kerja adalah sebagai sekumpulan perasaan menyenangkan dan tidak menyenangkan terhadap pekerjaan mereka. Perasaan terkait dengan sikap seseorang, maka kepuasan kerja dapat didefinisikan sebagai sebuah sikap karyawan yang timbul berdasarkan penilaian terhadap situasi di mana mereka bekerja. Secara sederhana juga terkait dengan pemenuhan kebutuhan hidup di mana karyawan yang merasa terpenuhi kebutuhannya akan mempersepsikan diri mereka sebagai karyawan yang memiliki kepuasan atas pekerjaannya.

4. Indikator Kepuasan Kerja

Menurut Weiss, Dawis dan England (1967) dalam Mangkunegara (2013) indikator kepuasan kerja terdiri dari:

1. Kesempatan menggunakan kemampuan

2. Pencapaian terhadap prestasi

3. Aktivitas

4. Kemajuan dalam keahlian

5. Wewenang

6. Kebijakan perusahaan

7. Kompensasi

8. Interaksi sosial

9. Kreativitas

10. Kebebasan

11. Keamanan

12. Kesempatan melakukan sesuatu

13. Status sosial

14. Nilai moral

15. Pengakuan

16. Tanggung jawab

17. Supervisi mengenai keluhan karyawan

18. Supervisi mengenai teknik kerja

19. Varietas pekerjaan

\section{Pengertian Pengembangan Karir}

Menurut Rivai dan Sagala (2011:274), pengembangan karir adalah proses peningkatan kemampuan kerja individu yang dicapai dalam rangka mencapai karir yang diinginkan. Pengembangan karir adalah suatu kemungkinan-kemungkinan seorang karyawan sebagai individu dapat naik pangkat atau jabatan yang dihubungkan dengan kemampuan dan persyaratan karyawan tersebut sehingga dapat tercapai kepuasan kerja yang mendorong peningkatan kinerja dan perkembangan pribadinya, disesuaikan dengan rencana yang telah diatur oleh perusahaan (Soeprihantono, 2000). Pengembangan karir sebagai tugas perkembangan harus 
diwujudkan pekerja secara individual, sedangkan dari organisasi merupakan kegiatan dari manajemen sumber daya manusia. Pengembangan karir adalah suatu kondisi yang menunjukkan adanya peningkatan status seseorang dalam suatu organisasi pada jalur karir yang telah ditetapkan dalam organisasi yang bersangkutan (Samsudin, 2010:141). Tentunya, pengembangan karir yang dapat dilakukan salah satunya melalui promosi jabatan.

\section{Indikator Pengembangan Karir}

Berdasarkan dari beberapa kajian teori tersebut maka, indikator yang digunakan dalam penelitian ini terhadap pengembangan karir adalah faktor indvidu yang terdiri dari
a. Prestasi kerja,
b. Eksposur,
c. Kesetiaan terhadap organisasi
d. Kreativitas

Sementara itu indikator pengembangan karir faktor organisasional adalah:
a. Adanya dukungan manajer atau pimpinan
b. Adanya penyediaan informasi tentang karir
c. Adanya program pendidikan dan pelatihan
d. Adanya umpan balik

\section{Pengertian Lingkungan Kerja Fisik}

Menurut Nitisemito (1984:183), lingkungan kerja adalah segala sesuatu yang ada di sekitar para pekerja dan yang dapat mempengaruhi dirinya dalam menjalankan tugas-tugas yang dibebankan. Sementara itu, lingkungan kerja fisik merupakan kondisi yang terdapat disekitar tempat kerja, di mana para karyawan beraktivitas dan menghasilkan produktivitas sehari-harinya. Lingkup dari lingkungan kerja fisik mencakup setiap hal dari fasilitas baik di luar maupun di dalam gedung perusahaan, lokasi dan rancangan gedung sampai dengan jumlah cahaya dan suara yang menimpa ruang kerja, kebersihan, pewarnaan dinding dan lain-lainnya. Menurut Sedarmayanti (2009), lingkungan kerja fisik adalah semua keadaan berbentuk fisik yang terdapat di sekitar tempat kerja di mana dapat mempengaruhi karyawan baik secara langsung maupun tidak langsung. Lingkungan kerja fisik sendiri dapat dibagi dalam dua kategori. Kategori yang pertama adalah lingkungan yang berhubungan langsung dengan karyawan dan berada di dekat karyawan (seperti meja, kursi dan sebagainya).

\section{Indikator Lingkungan Kerja Fisik}

Berdasarkan dari beberapa kajian teori tersebut maka, indikator yang digunakan dalam penelitian ini terhadap lingkungan kerja fisik adalah:

a. Kebersihan di tempat kerja

b. Sirkulasi udara/pertukaran udara

c. Penerangan/cahaya di tempat kerja

d. Keamanan di tempat kerja

e. Kebisingan di tempat kerja

f. Fasilitas di tempat kerja

g. Temperatur di tempat kerja

h. Getaran mekanis di tempat kerja

i. Bau-bauan di tempat kerja 
j. Dekorasi di tempat kerja

\section{Hipotesis}

\section{Pengaruh Pengembangan Karir Terhadap Kepuasan Kerja}

Kepuasan kerja yang tinggi merupakan suatu tanda bahwa suatu organisasi atau perusahaan dikelola dengan baik dan pada dasarnya merupakan hasil manajemen perilaku yang efektif. Dengan adanya pengembangan karir yang dilakukan oleh perusahaan dapat membantu karyawan dalam mencapai kepuasan kerjanya sendiri. Dengan dilakukannya pengembangan karir maka karyawan akan dapat lebih terpacu dan terdorong untuk meningkatkan kemampuan kerja, pengetahuan serta nantinya menghasilkan suatu kinerja yang positif. Hal ini sesuai dengan yang diungkapkan oleh Rivai dan Sagala (2011:274) bahwa tujuan dilakukannya pengembangan karir adalah untuk menyesuaikan antara kebutuhan dan tujuan karyawan dengan kesempatan karir yang tersedia di perusahaan saat ini dan di masa mendatang. Pengembangan karir juga merupakan hal yang krusial di mana perusahaan dapat meningkatkan kinerja, meningkatkan sikap karyawan terhadap pekerjaannya dan membangun kepuasan kerja yang lebih tinggi. Dari uraian tersebut tampak bahwa pengembangan karir berpengaruh dalam meningkatkan kepuasan kerja karyawan.

\section{H1: Pengembangan Karir Berpengaruh Positif dan Signifikan Terhadap Kepuasan Kerja}

\section{Pengaruh Lingkungan Kerja Fisik Terhadap Kepuasan kerja}

Lingkungan kerja yang baik akan membantu meningkatkan konsentrasi karyawan dalam bekerja. Lingkungan kerja fisik merupakan lingkungan di mana para karyawan akan menghabiskan waktu mereka untuk bekerja sehingga penting bagi perusahaan untuk dapat menyediakan atau mempersiapkan lingkungan kerja fisik yang nyaman bagi para karyawan. Lingkungan kerja fisik yang nyaman, segar dan memenuhi standar akan memberikan kontribusi yang besar bagi hasil pencapaian kerja mereka. Menurut Nitisemito (1984:183), lingkungan kerja merupakan salah satu faktor yang menyebabkan semangat dan kegairahan kerja dalam pelaksanaan tugas.

\section{H2: Lingkungan Kerja Fisik Berpengaruh Positif dan Signifikan Terhadap Kepuasan Kerja}

\section{Pengaruh Pengembangan Karir Terhadap Kinerja}

Pengembangan karir merupakan hal yang diharapkan bagi setiap karyawan. Karyawan di dalam pekerjaannya akan berharap untuk dapat mengembangkan karirnya. Ini dikarenakan karyawan akan mengabdikan dirinya untuk perusahaan sehingga mendapat tambahan kemampuan dan keahlian merupakan salah satu dari harapan karyawan melalui program pengembangan karir tersebut. Seperti yang di ungkapkan oleh Rivai dan Sagala (2011:274), pengembangan karir adalah proses peningkatan kemampuan kerja individu yang dicapai dalam rangka mencapai karir yang diinginkan. Pengembangan karir adalah suatu kemungkinan-kemungkinan seorang karyawan sebagai individu dapat naik pangkat atau jabatan yang dihubungkan dengan kemampuan dan persyaratan karyawan tersebut sehingga dapat tercapai kepuasan kerja yang mendorong peningkatan kinerja dan perkembangan 
pribadinya, disesuaikan dengan rencana yang telah diatur oleh perusahaan (Soeprihantono, 2000).

\section{H3: Pengembangan Karir Berpengaruh Positif dan Signifikan Terhadap Kinerja}

\section{Pengaruh Lingkungan Kerja Fisik Terhadap Kinerja}

Lingkungan kerja fisik yang baik akan meningkatkan semangat serta gairah dari karyawan dalam bekerja. Lingkungan kerja fisik memiliki peranan penting dalam meningkatkan kualitas dari pekerjaan seorang karyawan. Lingkungan kerja fisik ini memiliki andil yang besar dalam membentuk perilaku bekerja dari seorang karyawan sehingga perusahaan harus memperhatikan dengan serius mengenai lingkungan kerja fisik ini. Menurut Nitisemito (1984:183), lingkungan kerja fisik merupakan kondisi yang terdapat disekitar tempat kerja, di mana para karyawan beraktivitas dan menghasilkan produktivitas sehari-harinya. Tentunya hal tersebut menunjukkan bahwa lingkungan kerja fisik sangat berhubungan erat dengan pencapaian hasil kerja dari seorang karyawan atau terdapat hubungan antara lingkungan kerja fisik terhadap kinerja karyawan.

\section{H4: Lingkungan Kerja Fisik Berpengaruh Positif dan Signifikan Terhadap Kinerja}

\section{Pengaruh Kepuasan Kerja Terhadap Kinerja}

Kepuasan kerja merupakan hal yang penting untuk dapat meningkatkan kinerja dari seorang individu karyawan dalam suatu perusahaan. Menurut Robbins (2003:78) dalam Wibowo (2010), kepuasan kerja adalah sikap umum terhadap pekerjaan seseorang yang menunjukkan perbedaan antara jumlah penghargaan yang diterima pekerja dan jumlah yang mereka yakini seharusnya mereka terima. Menurut Gibson (2000:110) dalam Wibowo (2010), mengatakan bahwa secara jelas terdapat hubungan antara kepuasan kerja karyawan terhadap kinerja karyawan. Dikatakan kepuasan kerja menyebabkan peningkatan kinerja sehingga pekerja yang merasa puas akan lebih produktif dalam bekerja

\section{H5: Kepuasan Kerja Berpengaruh Positif dan Signifikan Terhadap Kinerja}

\section{METODE PENELITIAN}

Jenis penelitian yang digunakan dalam penelitian ini adalah penelitian assosiatif atau sebab-akibat (kausal). Populasi dalam penelitian ini berjumlah 91 orang yang terdiri dari seluruh karyawan Kantor Cabang Perum DAMRI Mataram dengan menggunakan metode sensus. Teknik pengumpulan data yang digunakan dalam penelitian ini adalah angket atau kuesioner. Sementara alat pengumpulan data yang digunakan dalam penelitian ini adalah kuesioner. Dalam penelitian ini menggunakan kuesioner baku untuk variabel kepuasan kerja. 
1. Hasil

HASIL DAN PEMBAHASAN

a. Hasil Regresi Sub-Struktur 1

\begin{tabular}{|c|c|c|c|c|c|c|}
\hline \multicolumn{7}{|c|}{ Coefficients $^{\mathrm{a}}$} \\
\hline \multirow[b]{2}{*}{ Model } & & \multicolumn{2}{|c|}{ Unstandardized Coefficients } & \multirow{2}{*}{$\begin{array}{c}\text { Standardized } \\
\text { Coefficients }\end{array}$} & \multirow[b]{2}{*}{$\mathrm{t}$} & \multirow[b]{2}{*}{ Sig. } \\
\hline & & $\mathrm{B}$ & Std. Error & & & \\
\hline \multirow[t]{3}{*}{1} & (Constant) & 1.596 & .491 & & 3.253 & .002 \\
\hline & $\begin{array}{l}\text { PENGEMBANGAN } \\
\text { KARIR }\end{array}$ & .227 & .130 & .179 & 1.939 & .026 \\
\hline & $\begin{array}{l}\text { LINGKUNGAN KERJA } \\
\text { FISIK }\end{array}$ & .327 & .090 & .376 & 3.657 & .000 \\
\hline a. Depe & dent Variable: KEPUASA & ERJA & & & & \\
\hline
\end{tabular}

1) Pengaruh Langsung Pengembangan Karir $\left(X_{1}\right)$ Terhadap Kepuasan Kerja Karyawan $\left(\mathrm{Y}_{1}\right)$

Pengaruh antara pengembangan karir $\left(\mathrm{X}_{1}\right)$ terhadap kepuasan kerja $\left(\mathrm{Y}_{1}\right)$ mempunyai nilai koefisien jalur (beta) sebesar nilai koefisien jalur sebesar 0,179 . Hal ini berarti bahwa jika terjadi perubahan nilai pada pengembangan karir sebesar satuan maka kepuasan kerja karyawan akan berubah sebesar 0,179 . Begitu pula dengan nilai signifikansi sebesar 0,026 hal ini menunjukan bahwa nilai tersebut lebih kecil dari nilai probabiitas yang distandarkan sebesar 0,05. Ini berarti bahwa pengaruh pengembangan karir terhadap kepuasan kerja berpengaruh secara signifikan bagi karyawan Kantor Cabang Perum DAMRI Mataram.

2) Pengaruh Langsung Lingkungan Kerja Fisik $\left(\mathrm{X}_{2}\right)$ Terhadap Kepuasan Kerja $\left(\mathrm{Y}_{1}\right)$

Pengaruh antara lingkungan kerja fisik $\left(\mathrm{X}_{2}\right)$ terhadap kepuasan kerja $\left(\mathrm{Y}_{1}\right)$ mempunyai nilai koefisien jalur (beta) sebesar 0,376. Hal ini berarti bahwa jika terjadi perubahan nilai pada lingkungan kerja fisik sebesar satuan maka kepuasan kerja karyawan akan berubah sebesar 0,376. Begitu pula dengan nilai signifikansi sebesar 0,000 hal ini menunjukan bahwa nilai tersebut lebih kecil dari nilai probabiitas yang distandarkan sebesar 0,05 . Ini berarti bahwa pengaruh lingkungan kerja fisik terhadap kepuasan kerja berpengaruh secara signifikan bagi karyawan Kantor Cabang Perum DAMRI Mataram.

b. Hasil Regresi Sub-Struktur 2

\begin{tabular}{|c|c|c|c|c|c|c|}
\hline \multicolumn{7}{|c|}{ Coefficients $^{\mathrm{a}}$} \\
\hline & \multirow{2}{*}{ Model } & \multicolumn{2}{|c|}{$\begin{array}{c}\text { Unstandardized } \\
\text { Coefficients }\end{array}$} & \multirow{2}{*}{$\begin{array}{c}\begin{array}{c}\text { Standardized } \\
\text { Coefficients }\end{array} \\
\text { Beta }\end{array}$} & \multirow[t]{2}{*}{$\mathrm{t}$} & \multirow[t]{2}{*}{ Sig. } \\
\hline & & B & $\begin{array}{l}\text { Std. } \\
\text { Error }\end{array}$ & & & \\
\hline \multirow[t]{4}{*}{1} & (Constant) & 4.738 & .485 & & 9.779 & .000 \\
\hline & PENGEMBANGAN KARIR & .311 & .124 & .283 & 2.519 & .014 \\
\hline & LINGKUNGAN KERJA FISIK & .111 & .090 & .146 & 1.935 & .020 \\
\hline & KEPUASAN KERJA & .224 & .099 & .258 & 2.256 & .027 \\
\hline \multicolumn{3}{|c|}{ a. Dependent Variable: KINERJA } & & & & \\
\hline
\end{tabular}


1) Pengaruh Langsung Pengembangan Karir $\left(\mathrm{X}_{1}\right)$ Terhadap Kinerja $\left(\mathrm{Y}_{2}\right)$ Hasil perhitungan analisa jalur (path analysis) di atas menunjukkan, bahwa pengembangan karir $\left(\mathrm{X}_{1}\right)$ mempunyai pengaruh yang signifikan terhadap kinerja. Hal ini dibuktikan dengan nilai koefisien jalur sebesar 0,283 dengan nilai signifikansi sebesar 0,014 atau lebih kecil dari taraf signifikansi yang disyaratkan sebesar 0,05 . Dengan demikian hipotesis penelitian yang menyatakan pengembangan karir berpengaruh signifikan terhadap kinerja terbukti.

2) Pengaruh Langsung Lingkungan Kerja Fisik (X2) Terhadap Kinerja (Y2) Pengaruh antara lingkungan kerja fisik $\left(\mathrm{X}_{2}\right)$ terhadap kinerja $\left(\mathrm{Y}_{1}\right)$ mempunyai nilai koefisien jalur (beta) sebesar 0,146. Hal ini berarti bahwa jika terjadi perubahan nilai pada lingkungan kerja fisik sebesar satuan maka kinerja karyawan akan berubah sebesar 0,146. Begitu pula dengan nilai signifikansi sebesar 0,020 . Hal ini menunjukan bahwa nilai tersebut lebih kecil dari nilai probabiitas yang distandarkan sebesar 0,05. Ini berarti bahwa pengaruh lingkungan kerja fisik terhadap kinerja berpengaruh secara signifikan bagi karyawan Kantor Cabang Perum DAMRI Mataram.

3) Pengaruh Langsung Kepuasan Kerja (Y1) Terhadap Kinerja (Y2)

Pengaruh antara kepuasan kerja $\left(\mathrm{Y}_{1}\right)$ terhadap kinerja $\left(\mathrm{Y}_{2}\right)$ mempunyai nilai koefisien jalur (beta) sebesar 0,258. Hal ini berarti bahwa jika terjadi perubahan nilai pada kepuasan kerja sebesar satuan maka kinerja karyawan akan berubah sebesar 0,258. Begitu pula dengan nilai signifikansi sebesar 0,027 hal ini menunjukan bahwa nilai tersebut lebih kecil dari nilai probabiitas yang distandarkan sebesar 0,05 . Ini berarti bahwa pengaruh kepuasan kerja terhadap kinerja berpengaruh secara signifikan bagi karyawan Kantor Cabang Perum DAMRI Mataram.

4) Pengaruh Tidak Langsung Pengembangan Karir (X1) Terhadap Kinerja (Y2) Melalui Kepuasan Kerja (Y1)

Dalam analisa jalur, disamping melihat pengaruh langsung antara variabel independen terhadap variabel dependen, dilihat juga pengaruh tidak langsung antara keduanya. Di dalam penelitian ini, terdapat pengaruh tidak langsung antara variabel pengembangan karir terhadap kinerja karyawan melalui kepuasan kerja. Dari hasil analisa tersebut, maka untuk menghitung pengaruh tidak langsung antara pengembangan karir terhadap kinerja melalui kepuasan kerja adalah sebagai berikut:

- Pengembangan Karir terhadap kinerja melalui kepuasan kerja

$$
0,179 \times 0,258=0,046
$$

Dari perhitungan tersebut, memberi arti bahwa terdapat pengaruh yang tidak langsung antara variabel pengembangan karir dengan kinerja akan tetapi melalui variabel kepuasan kerja memiliki nilai koefisien jalur sebesar 0,046 yang berarti bahwa setiap perubahan yang terjadi pada lingkungan kerja fisik sebesar satuan akan mempengerahui kinerja karyawan melalui kepuasan kerja sebesar 0,046.

5) Pengaruh Tidak Langsung Lingkungan Kerja Fisik (X2) Terhadap Kinerja (Y2) Melalui Kepuasan Kerja (Y1)

Dalam analisa jalur, disamping melihat pengaruh langsung antara variabel independen terhadap variabel dependen, dilihat juga pengaruh tidak langsung antara keduanya. Di dalam penelitian ini, terdapat 
pengaruh tidak langsung antara variabel lingkungan kerja fisik terhadap kinerja karyawan melalui kepuasan kerja. Dari hasil analisa tersebut, maka untuk menghitung pengaruh tidak langsung antara lingkungan kerja fisik terhadap kinerja melalui kepuasan kerja adalah sebagai berikut:

- Lingkungan kerja fisik terhadap kinerja melalui kepuasan kerja $0,398 \times 0,267=0,106$

Dari perhitungan tersebut, memberi arti bahwa terdapat pengaruh yang tidak langsung antara variabel lingkungan kerja fisik dengan kinerja akan tetapi melalui variabel kepuasan kerja memiliki nilai koefisien jalur sebesar 0,106 yang berarti bahwa setiap perubahan yang terjadi pada lingkungan kerja fisik sebesar satuan akan mempengaruhi kinerja karyawan melalui kepuasan kerja sebesar 0,106.

\section{PEMBAHASAN}

\section{Pengaruh Langsung Pengembangan Karir $\left(\mathbf{X}_{1}\right)$ Terhadap Kepuasan Kerja Karyawan ( $\left.\mathbf{Y}_{1}\right)$}

Berdasarkan data empiris yang ada dapat dilihat bahwa pendidikan terakhir dari responden yang dijadikan sampel pada penelitian ini yang dominan adalah SMA dengan jumlah 52 orang atau $57,4 \%$ lalu diikuti oleh responden yang SMP sebanyak 28 orang atau $30,7 \%$, untuk SD sebanyak 10 orang atau 10,9\% dan S1 sebanyak 1 orang atau 1,0\%. Hal ini menunjukan bahwa tingkat kompetensi rata-rata karyawan Kantor Cabang Perum DAMRI Mataram berada pada tingkat yang sedang, karyawan menyadari akan hal itu dan memahami betul pentingnya pengembangan karir bagi dirinya sendiri hal ini dapat dilihat dari beberapa tanggapan/persepsi karyawan terkait indikator pengembangan karir seperti karyawan selalu meningkatkan kemampuan sesuai dengan tuntutan perusahaan, promosi jabatan yang dilakukan berhasil meningkatkan prestasi, promosi akan membuat kerja karyawan jadi lebih baik, karyawan menyadari bahwa hanya karyawan yang rajin saja yang dapat berkembang, karyawan menyadari bahwa hanya karyawan yang memliki inisiatif yang dapat berkembang dan karyawan menyadari bahwa hanya karyawan yang memiliki inovasi yang dapat berkembang ratarata menjawab sudah sesuai dengan apa yang diusahakan oleh karyawan itu sendiri, sementara itu pengembangan karir yang dilakukan dari sisi perusahaan menurut tanggapan/persepsi karyawan atas indikator manajer/pimpinan memberikan dukungan kepada karyawan dalam melakukan pengembangan karir, organisasi/perusahaan selalu berusaha memberikan informasi-informasi terkait pengembangan karir, secara terencana tiap karyawan pasti mendapat kesempatan mengikuti pendidikan, secara terstruktur tiap karyawan diberi kesempatan mengikuti pelatihan, umpan balik (memberikan informasi kembali terkait pengembangan karir) sangat besar manfaatnya untuk menambah kedewasaan rata-rata menjawab sudah sesuai berdasarkan kategori yang ada. Hal ini menunjukkan bahwa Kantor Cabang Perum DAMRI Mataram memberikan kesempatan untuk maju kepada para karyawannya. Hal ini sesuai dengan teori yang dikemukakan oleh As'ad (2003) dalam Wahyuni (2012) bahwa faktor yang mempengaruhi suatu kepuasan kerja adalah dengan diberikannya kesempatan maju bagi karyawan dengan melakukan pengembangan karir. Sehingga, pengembangan karir yang dilakukan oleh karyawan secara individu dan pengembangan karir yang diberikan atau dilakukan oleh Kantor Cabang Perum DAMRI Mataram dapat membangun dan memberikan suatu kepuasan kerja yang lebih tinggi bagi karyawan itu sendiri. 


\section{Pengaruh Langsung Lingkungan Kerja Fisik (X2) Terhadap Kepuasan Kerja (Y)}

Berdasarkan data empiris yang ada dapat dilihat bahwa jabatan dari responden yang dijadikan sampel pada penelitian ini di dominasi oleh pengemudi sebanyak 53 orang atau 58,2\%, kemudian diikuti oleh jabatan pelaksana usaha sebanyak 22 orang atau $24,2 \%$, pelaksana teknis sebanyak 9 orang atau 9,8\%, administrasi gudang sebanyak 1 orang atau $1,0 \%$, pelaksana gudang sebanyak 1 orang atau $1,0 \%$, bendahara 1 orang atau 1,0\%, staf keuangan sebanyak 2 orang atau 2,1\% dan staf kepegawaian dan umum sebanyak 2 orang atau 2,1\%. Dalam penelitian ini responden di dominasi oleh karyawan Kantor Cabang Perum DAMRI Mataram berasal dari pengemudi, kemudian pelaksana usaha dan pelaksana teknis. Ketiga pekerjaan tersebut tidak berada di dalam ruangan melainkan berada di luar ruangan. Namun selain itu juga terdapat beberapa pekerjaan yang mengharuskan karyawannya berada atau bekerja di dalam ruangan seperti karyawan yang memegang jabatan atau bagian administrasi gudang, bagian pelaksana gudang, bendahara, staf keuangan dan staf kepegawaian dan umum. Dalam lingkungan kerja fisik $\left(\mathrm{X}_{2}\right)$ terdapat beberapa indikator seperti kebersihan di ruang kerja dan tempat bekerja membuat nyaman dalam bekerja, pertukaran udara di ruang kerja atau tempat kerja membuat kesegaran fisik, penerangan/cahaya di tempat bekerja mendukung pekerjaan para karyawan, dalam melakukan pekerjaan karyawan merasa aman terhadap pekerjaan yang sedang dilakukannya, adanya ketersediaan satuan pengamanan (satpam) di tempat berkeja membuat karyawan merasa aman dalam bekerja, ketersediaan sarana atau fasilitas kerja telah mendukung pekerjaan para karyawan serta tata letak di tempat kerja saat ini membuat hasil kerja menjadi maksimal. Berdasarkan jawaban dari responden terhadap indikator tersebut masuk dalam rata-rata kategori nyaman. Hal ini mengindikasikan bahwa lingkungan kerja fisik yang ada menunjukkan kondisi yang baik sehingga hubungan langsung antara lingkungan kerja fisik $\left(\mathrm{X}_{2}\right)$ terhadap kepuasan kerja $\left(\mathrm{Y}_{1}\right)$ berpengaruh positif dan signifikan. Penelitian ini mendukung teori yang dikemukakan oleh Nitisemito (1984:183) lingkungan kerja merupakan salah satu faktor yang menyebabkan semangat dan kegairahan kerja dalam pelaksanaan tugas. Ketika karyawan bersemangat dalam bekerja yang dicerminkan dengan baiknya kondisi lingkungan kerja fisiknya, maka pada saat itu terciptanya kepuasan kerja akan lingkungan kerja fisik dari karyawan tersebut.

\section{Pengaruh Langsung Pengembangan Karir (X1) Terhadap Kinerja (Y2)}

Menurut Rivai dan Sagala (2011:274) bahwa pengembangan karir adalah proses peningkatan kemampuan kerja individu yang dicapai dalam rangka mencapai karir yang diinginkan. Begitupun menurut Soeprihantono (2000) bahwa pengembangan karir adalah suatu kemungkinan-kemungkinan seorang karyawan sebagai individu dapat naik pangkat atau jabatan yang dihubungkan dengan kemampuan dan persyaratan karyawan tersebut sehingga dapat tercapai kepuasan kerja yang mendorong peningkatan kinerja dan perkembangan pribadinya, disesuaikan dengan rencana yang telah diatur oleh perusahaan. Berdasarkan data empiris yang ada Hal ini bisa terjadi karena apabila dilihat dari data empiris yang ada bahwa masa kerja dari responden yang dijadikan sampel pada penelitian ini di dominasi oleh karyawan berada pada masa kerja 0-5 tahun sebanyak 41 orang atau $45,3 \%$ kemudian diikuti oleh karyawan yang memiliki masa kerja 5-10 tahun sebanyak 23 orang atau 25,2\%. Hal Ini menunjukan bahwa pengembangan karir yang dilakukan oleh Kantor Cabang Perum DAMRI bisa mempengaruhi kinerja secara signifikan. Ini dikarenakan pengembangan karir yang dilakukan oleh Perum DAMRI melalui pendidikan dan pelatihan yang dilakukan 2 tahun sekali pada masing-masing bidang kerja, sehingga dengan dilakukannya 
pendidikan dan pelatihan tersebut, karyawan dengan cepat bisa untuk meningkatkan kemampuannya yang berujung pada meningkatnya kinerja dengan demikian karyawan akan bisa untuk mencapai jenjang karir yang diinginkan.

\section{Pengaruh Langsung Lingkungan Kerja Fisik (X2) Terhadap Kinerja (Y2)}

Berdasarkan data empiris yang ada bahwa responden penelitian yang dijadikan sampel pada penelitian ini jika didasarkan pada jabatan di dominasi oleh pengemudi sebanyak 53 orang atau 58,2\%, kemudian diikuti oleh jabatan pelaksana usaha sebanyak 22 orang atau $24,2 \%$, pelaksana teknis sebanyak 9 orang atau 9,8\% hal ini menunjukkan bahwa karyawan DAMRI yang ada pada jabatan tersebut kebanyakan bekerja di luar ruangan atau di lapangan. Seperti pengemudi yang jarang berada di dalam kantornya dan lebih sering berada pada bus yang dikemudikannya, pelaksana usaha yang berada di luar kantor untuk melayani para penumpang yang membawa barang-barang serta pelaksana teknis atau mekanik yang bertugas melakukan perbaikan dan perawatan pada bus-bus DAMRI yang ada. Walaupun demikian karyawan yang bekerja di luar ruangan juga tetap memiliki ruangan tersendiri, seperti contoh ruangan untuk mereka beristirahat. Selain itu juga terdapat karyawan yang bekerja di dalam ruangan seperti karyawan yang memegang jabatan atau bagian administrasi gudang, bagian pelaksana gudang, bendahara, staf keuangan dan staf kepegawaian dan umum. Terdapat beberapa indikator pada lingkungan kerja fisik $\left(\mathrm{X}_{2}\right)$ seperti kebersihan di ruang kerja dan tempat bekerja membuat nyaman dalam bekerja, pertukaran udara di ruang kerja atau tempat kerja membuat kesegaran fisik, penerangan/cahaya di tempat bekerja mendukung pekerjaan para karyawan, dalam melakukan pekerjaan karyawan merasa aman terhadap pekerjaan yang sedang dilakukannya, adanya ketersediaan satuan pengamanan (satpam) di tempat berkeja membuat karyawan merasa aman dalam bekerja, ketersediaan sarana atau fasilitas kerja telah mendukung pekerjaan para karyawan serta tata letak di tempat kerja saat ini membuat hasil kerja menjadi maksimal. Berdasarkan jawaban dari responden terhadap indikator tersebut masuk dalam rata-rata kategori nyaman. Terlebih lagi pada indikator adanya ketersediaan satuan pengamanan (satpam) di tempat bekerja hasil rata-rata responden menjawab sangat nyaman. Ini membuat karyawan merasa nyaman dalam bekerja sehingga karyawan dapat berkonsentrasi dalam bekerja dan membuat karyawan dapat menghasilkan kinerja yang lebih baik. hal ini mengindikasikan bahwa lingkungan kerja fisik yang ada menunjukkan kondisi yang baik sehingga hubungan langsung antara lingkungan kerja fisik $\left(\mathrm{X}_{2}\right)$ terhadap kinerja $\left(\mathrm{Y}_{2}\right)$ berpengaruh positif dan signifikan. Hal ini sesuai dengan yang dikemukakan oleh Nitisemito (1984:183), lingkungan kerja fisik merupakan kondisi yang terdapat disekitar tempat kerja, di mana para karyawan beraktivitas dan menghasilkan produktivitas sehari-harinya.

\section{Pengaruh Langsung Kepuasan Kerja (Y1) Terhadap Kinerja (Y2)}

Berdasarkan data empiris yang ada dapat dlihat bahwa usia responden yang dominan adalah berusia 31-40 tahun berjumlah 60 orang atau sebesar 65,9\%. Hal ini menunjukan bahwa rata-rata tingkat kematangan karyawan Kantor Cabang Perum DAMRI Mataram dalam bekerja sudah cukup tinggi dalam sisi usia. Sehingga karyawan mampu untuk merasakan apa yang berkaitan dengan pekerjaan mereka terlebih lagi dari sisi kepuasan kerja. Dari beberapa indikator kepuasan kerja seperti kesempatan yang dimiliki karyawan untuk menggunakan kemampuannya dalam menyelesaikan pekerjaan, pencapaian terhadap prestasi yang didapatkan dari pekerjaan membuat karyawan merasa puas, kegiatan kerja yang dilakukan membuat karyawan 
merasa puas, kesempatan yang ada untuk memiliki kemampuan lebih dalam keahlian dan keterampilan kerja membuat karyawan merasa puas, kebijakan perusahaan yang diterapkan membuat karyawan merasa puas, hubungan yang terjalin/interaksi dengan sesama rekan kerja membuat karyawan merasa puas, karyawan memiliki kesempatan untuk berkreasi dalam pekerjaan yang dilakukan, pekerjaan yang karyawan lakukan memberikan ketetapan (keamanan) yang stabil, kesempatan melakukan sesuatu untuk orang lain membuat karyawan merasa puas, karyawan memiliki kesempatan untuk menjadi "sesorang" dalam lingkungan kerjanya, pekerjaan yang dilakukan tidak bertentangan dengan hati nurani, cara atasan menangani keluhan karyawan, cara atasan melakukan pengawan terkait hal-hal yang teknis, dan kesempatan dalam melakukan kegiatan lain dapat dilihat tanggapan atau persepsi karyawan termasuk dalam kategori puas. Tentunya apabila melihat kategori tersebut maka kepuasan kerja akan berpengaruh positif dan signifikan terhadap kinerja karyawan itu sendiri. Hal ini sesuai dengan teori yang dikemukakan oleh Gibson (2000) dalam Wibowo (2010), yang mengatakan bahwa secara jelas terdapat hubungan antara kepuasan kerja karyawan terhadap kinerja karyawan. Dikatakan kepuasan kerja menyebabkan peningkatan kinerja sehingga pekerja yang merasa puas akan lebih produktif dalam bekerja.

\section{Pengaruh Tidak Langsung Pengembangan Karir (X1) Terhadap Kinerja (Y2) Melalui Kepuasan Kerja (Y1)}

Dalam analisa jalur, disamping melihat pengaruh langsung antara variabel independen terhadap variabel dependen, dilihat juga pengaruh tidak langsung antara keduanya. Di dalam penelitian ini, terdapat pengaruh tidak langsung antara variabel pengembangan karir terhadap kinerja karyawan melalui kepuasan kerja. Dari hasil analisa tersebut, maka untuk menghitung pengaruh tidak langsung antara pengembangan karir terhadap kinerja melalui kepuasan kerja adalah sebagai berikut:

- Pengembangan Karir terhadap kinerja melalui kepuasan kerja

$$
0,179 \times 0,258=0,046
$$

Dari perhitungan tersebut, memberi arti bahwa terdapat pengaruh yang tidak langsung antara variabel pengembangan karir dengan kinerja akan tetapi melalui variabel kepuasan kerja memiliki nilai koefisien jalur sebesar 0,046 yang berarti bahwa setiap perubahan yang terjadi pada lingkungan kerja fisik sebesar satuan akan mempengerahui kinerja karyawan melalui kepuasan kerja sebesar 0,046. Berdasarkan data empiris yang ada dapat dilihat bahwa pendidikan terakhir dari responden yang dijadikan sampel pada penelitian ini yang dominan adalah SMA dengan jumlah 52 orang atau 57,4\% lalu diikuti oleh responden yang SMP sebanyak 28 orang atau 30,7\%, untuk SD sebanyak 10 orang atau $10,9 \%$ dan S1 sebanyak 1 orang atau 1,0\%. Hal ini menunjukan bahwa rata-rata pendidikan atau kompetensi yang dimiliki oleh karyawan Kantor Cabang Perum DAMRI Mataram pada tingkat yang sedang. Karyawan sebagai individu menyadari perlunya peningkatan akan kompetensi dirinya sendiri secara pribadi, hal ini akan membantu karyawan untuk meningkatkan kemampuannya dalam bekerja. Karyawan menyadari bahwa dengan meningkatkan kemampuannya dalam bekerja maka hal tersebut akan memberikan kesempatan yang besar bagi dirinya agar dapat naik pangkat atau jabatan dari sebelumnya. Hal ini akan memberikan suatu kepuasan bagi karyawan. Tentunya hal ini harus di fasilitasi oleh perusahaan dalam meningkatkan kemampuan para karyawan dalam bekerja karena apabila karyawan meningkat kemampuannya dan memperoleh kepuasannya maka kinerjanya pun akan meningkat dan menguntungkan perusahaan. Meningkatnya kinerja ini juga dihasilkan secara tidak langsung, artinya pengembangan karir yang dilakukan terlebih dahulu 
memberikan rasa puas kepada diri karyawan dan pada akhirnya akan meningkatkan kinerja dari karyawan tersebut. Hal ini sesuai dengan yang dikatakan oleh Soeprihantono (2000) bahwa Pengembangan karir memberikan suatu kemungkinankemungkinan seorang karyawan sebagai individu dapat naik pangkat atau jabatan yang dihubungkan dengan kemampuan dan persyaratan karyawan tersebut sehingga dapat tercapai kepuasan kerja yang mendorong peningkatan kinerja dan perkembangan pribadinya, disesuaikan dengan rencana yang telah diatur oleh perusahaan.

\section{Pengaruh Tidak Langsung Lingkungan Kerja Fisik (X2) Terhadap Kinerja (Y2) Melalui Kepuasan Kerja (Y1)}

Dalam analisa jalur, disamping melihat pengaruh langsung antara variabel independen terhadap variabel dependen, dilihat juga pengaruh tidak langsung antara keduanya. Di dalam penelitian ini, terdapat pengaruh tidak langsung antara variabel lingkungan kerja fisik terhadap kinerja karyawan melalui kepuasan kerja. Dari hasil analisa tersebut, maka untuk menghitung pengaruh tidak langsung antara lingkungan kerja fisik terhadap kinerja melalui kepuasan kerja adalah sebagai berikut:

- Lingkungan kerja fisik terhadap kinerja melalui kepuasan kerja

$$
0,398 \times 0,267=0,106
$$

Dari perhitungan tersebut, memberi arti bahwa terdapat pengaruh yang tidak langsung antara variabel lingkungan kerja fisik dengan kinerja akan tetapi melalui variabel kepuasan kerja memiliki nilai koefisien jalur sebesar 0,106 yang berarti bahwa setiap perubahan yang terjadi pada lingkungan kerja fisik sebesar satuan akan mempengaruhi kinerja karyawan melalui kepuasan kerja sebesar 0,106. Hal ini sesuai dengan teori yang dikatakan oleh Bakotic dan Tomislav (2013) dalam Ratnasari dan Dewi (2013) bahwa Lingkungan kerja fisik yang bagus akan berbanding lurus dengan kepuasan kerja karyawan ataupun hasil dari kinerja karyawan.

Berdasarkan data empiris yang ada dapat dilihat bahwa jabatan dari responden yang dijadikan sampel pada penelitian ini di dominasi oleh pengemudi sebanyak 53 orang atau 58,2\%, kemudian diikuti oleh jabatan pelaksana usaha sebanyak 22 orang atau $24,4 \%$, pelaksana teknis sebanyak 9 orang atau 9,8\%, administrasi gudang sebanyak 1 orang atau $1,0 \%$, pelaksana gudang sebanyak 1 orang atau $1,0 \%$, bendahara 1 orang atau 1,0\%, staf keuangan sebanyak 2 orang atau 2,1\% dan staf kepegawaian dan umum sebanyak 2 orang atau 2,1\%. Hal ini mengindikasikan bahwa terdapat dua lingkungan kerja fisik yang berbeda, pada jabatan atau bagian pengemudi, pelaksana usaha dan pelaksana teknis bekerja di luar ruangan sementara sisanya yakni admnistrasi gudang, pekasana gudang, bendahara, staf keuangan dan staf kepegawaian dan umum bekerja di dalam ruangan. Tentunya hal ini menimbulkan lingkungan kerja fisik yang berbeda satu sama lain, namun berdasarkan hasil perhitungan statistik yang ada menunjukan bahwa terdapat pengaruh tidak langsung antara lingkungan kerja fisik terhadap kinerja melalui kepuasan kerja. Ini menujukan, dalam penelitian ini lingkungan kerja fisik yang ada tidak mempengaruhi secara langsung terhadap kinerja karyawan melainkan lingkungan kerja fisik tersebut terlebih dahulu mempengaruhi kepuasan kerja karyawan dan selanjutnya mempengaruhi kinerja dari karyawan itu secara postif. 


\section{Kesimpulan}

\section{KESIMPULAN DAN SARAN}

Berdasarkan hasil penelitian yang telah dilakukan mengenai pengaruh pengembangan karir dan lingkungan kerja fisik terhadap kepuasan kerja dan kinerja karyawan pada Kantor Cabang Perum DAMRI Mataram, dapat diperoleh kesimpulan sebagai berikut:

1. Pengembangan karir $\left(\mathrm{X}_{1}\right)$ berpengaruh secara signifikan terhadap kepuasan kerja $\left(\mathrm{Y}_{1}\right)$ karyawan pada Kantor Cabang Perum DAMRI Mataram.

2. Lingkungan kerja fisik $\left(\mathrm{X}_{2}\right)$ berpengaruh secara signifikan terhadap kepuasan kerja $\left(\mathrm{Y}_{1}\right)$ karyawan pada Kantor Cabang Perum DAMRI Mataram.

3. Pengembangan karir $\left(\mathrm{X}_{1}\right)$ berpengaruh secara signifikan terhadap kinerja $\left(\mathrm{Y}_{2}\right)$ karyawan pada Kantor Cabang Perum DAMRI Mataram.

4. Lingkungan kerja fisik $\left(\mathrm{X}_{2}\right)$ berpengaruh secara signifikan terhadap kinerja $\left(\mathrm{Y}_{2}\right)$ karyawan pada Kantor Cabang Perum DAMRI Mataram.

5. Kepuasan kerja $\left(\mathrm{Y}_{1}\right)$ berpengaruh secara signifikan terhadap kinerja $\left(\mathrm{Y}_{2}\right)$ karyawan secara signifikan pada Kantor Cabang Perum DAMRI Mataram.

\section{Saran}

Berdasarkan hasil dari penelitian yang telah diuraikan, maka dapat di sampaikan saran sebagai berikut:

1. Dalam pengembangan karir, karyawan perlu memperhatikan atau dapat melakukan sesuatu yang lebih dalam bekerja. Tentunya dengan lebih dominannya tingkat pendidikan karyawan Kantor Cabang Perum DAMRI Mataram yang lebih banyak di dominasi SMA cara yang dapat di tempuh juga untuk lebih mempercepat pengembangan karir adalah dengan cara bekerja lebih dari jam kerja yang ditetapkan, hal inilah yang perlu diperhatikan oleh karyawan Kantor Cabang Perum DAMRI Mataram tanpa mengabaikan indikator lain yang sudah sesuai pada pengembangan karir tersebut.

2. Untuk lingkungan kerja fisik karyawan, Kantor Cabang Perum DAMRI Mataram perlu memperhatikan seperti getaran mekanis yang terjadi mengganggu konsentrasi dalam bekerja, bau-bauan di tempat kerja mengganggu konsentrasi dalam bekerja dan fasilitas yang ada sudah sesuai dengan kebutuhan bekerja hal ini perlu diperhatikan dengan lebih teliti. Artinya, karyawan-karyawan yang bekerja pada bagian-bagian yang mengharuskan dirinya bersentuhan langsung dengan getaran mekanis yang ada, yang bersentuhan langsung dengan bau-bauan di tempat kerjanya serta dalam memberikan fasilitas yang ada seperti karyawan pada bagian pengemudi, pelaksana usaha serta pelaksana teknis utamanya perlu diperhatikan kondisi kesehatannya serta perusahaan juga perlu memperhatikan bahkan menambah fasilitas-fasilitas peralatan kerja untuk karyawan hal ini untuk menunjang dari peningkatan kepuasan serta kinerja kerja dari karyawan itu sendiri. Tanpa mengabaikan karyawan-karyawan yang bekerja di dalam ruangan.

3. Untuk kepuasan kerja, yang perlu diperhatikan adalah karyawan diberikan kesempatan dalam menggunakan wewenang kepada rekan kerja artinya karyawan dapat menjadi atasan di lingkungan kerja mereka sehingga dapat menggunakan wewenang tersebut hal ini akan menimbulkan kepuasan yang lebih dalam bekerja, selain itu antara gaji yang diterima dengan jumlah pekerjaan yang dilakukan perlu diperhatikan kembali agar karyawan dapat merasa lebih puas hal ini bisa dilakukan dengan menambah gaji dari karyawan atau bisa dengan mengurangi jumlah pekerjaan yang harus dikerjakan sehingga antara gaji yang diterima dengan jumlah 
pekerjaan yang dilakukan menjadi lebih sesuai, selain itu juga yang perlu diperhatikan bagi atasan adalah dengan memberikan pujian terhadap karyawannya atas pekerjaan yang telah diselesaikannya dan memberikan kebebasan kepada karyawan untuk menggunakan penilaian kerja terhadap dirinya sendiri tentunya hal ini tidak mengabaikan indikator-indikator lain yang juga harus diperhatikan.

4. Untuk kinerja karyawan, rata-rata sudah tinggi namun hal yang perlu diperhatikan oleh Kantor Cabang Perum DAMRI Mataram adalah terkait dengan faktor-faktor yang dapat meningkatkan kembali kinerja tersebut, seperti lebih memperhatikan kembali kepuasan kerja dan khususnya bagi lingkungan kerja fisik perusahaan harus memperhatikan secara lebih cermat dan teliti, perusahaan perlu untuk memberikan tambahan fasilitas atau peralatan bagi karyawan untuk bekerja seperti penambahan fasilitas pada alat-alat keselamatan di masing-masing armada bus, alat-alat untuk melakukan perawatan pada bus dan sebagainya. 


\section{DAFTAR PUSTAKA}

1998.Perarturan Menteri BUMN Nomor 13 Tahun 1998 tentang perusahaan umum (PERUM).

Arikunto, S.1998.Manajemen Penelitian.Jakarta: PT. Rineke Cipta.

Handoko, H T. 2012.Manajemen Personalia dan Sumberdaya Manusia.Yogyakarta: BPFE-Yogyakarta.

Mangkunegara, A P.2013.Manajemen Sumber Daya Manusia Perusahaan.Bandung: PT Remaja Rosdakarya.

Nitisemito, A S.1984.Manajemen Personalia.Jakarta: PT Ghalia Indonesia.

Prawirosentono, S.1999.Manajemen Sumber Daya Manusia Kebijakan Kinerja Karyawan. Yogyakarta: BPFE-Yogyakarta.

Ratnasari I P, Dewi K.2013.Pengaruh Motivasi, Lingkungan Kerja Fisik dan Kepemimpinan Terhadap Kepuasan Kerja Karyawan. Jurnal Ilmiah Manajemen Vol 13, No 1, April, 1991-1926.

Rivai, V.2004.Manajemen Sumber Daya Manusia untuk Perusahaan dari Teori ke Praktik. Jakarta: PT Rajagrafindo Persada.

Rivai V, Sagala E J.2011.Manajemen Sumber Daya Manusia. Jakarta: PT RajaGrafindo Persada.

Sedarmayanti. 2009. Manajemen Sumber Daya Manusia.Bandung: PT Refika Aditama.

Soeprihantono, J.2000.Penilaian Pelaksanaan Pekerjaan dan Pengembangan Karyawan. Yogyakarta: BPFE-Yogyakarta.

Sugiyono. 2013. Metode Penelitian Kuantitatif, Kualitatif dan R\&D. Bandung: Alfabeta.

Tsui, Anne, Pearce, Porter. 1997. Alternative Approaches to the Employee Organization Relationship: Does Investment in Employee Pay off. Academy of Management Journal. Vol 40. No 5, 1089-1121.

Wahyuni Y. 2014.Pengaruh Konflik Peran dan Beban Kerja Terhadap Kepuasan Kerja Dengan Burnout Sebagai Variabel Intervening Pada Karyawan PT. Bank Negara Indonesia (persero) tbk Kantor Cabang Utama Mataram.Tesis pada Magister Manajemen Universitas Mataram: Tidak diterbitkan.

Wibowo. 2012. Manajemen Kinerja. Jakarta: PT Rajagrafindo Persada.

Wirawan. 2009. Evaluasi Kinerja Sumber Daya Manusia. Jakarta: Salemba Empat.

Zulhana. 2012. Analisis faktor-Faktor Yang Membentuk Kepuasan Kerja Bidang (Studi Pada Puskesmas di Kabupaten Lombok Barat). Tesis pada Magister Manajemen Universitas Mataram: tidak diterbitkan. 